\title{
Role of Vyaghri Haritaki Avaleha and Anu Taila Nasya in the management of Dushta Pratishyaya (Chronic Sinusitis)
}

\author{
Research Article
}

\section{Parth P Dave ${ }^{1^{*}}$, Kunjal H Bhatta ${ }^{2}$, Vaghela DB $^{3}$, Dhiman $\mathrm{KS}^{4}$}

1. PhD Scholar, 3. Assistant Lecturer,

Department of Shalakya Tantra, IPGT \& RA. Gujrat Ayurveda University. Jamnagar. Gujrat

2. Assistant Lecturer, Department of Shalakya Tantra, J.S. Ayurved College, Nadiad. Gujrat, India

3. Director General, CCRAS, ministry of AYUSH, New Delhi, India

\begin{abstract}
Chronic sinusitis-rhinosinusiis affects $5-15 \%$ of the urban population. The prevalence of sinusitis (146/1000 population) has been reported to exceed that of any other chronic condition. The features of the disease Dushta Pratishyaya in general are similar to that of chronic sinusitis (rhinosinustis) in modern science. The study was planned to evaluate the role of Vyaghri Haritaki Avaleha and Anutaila Nasya in the management of Dushta Pratishyaya (Chronic Sinusitis). Total 30 patients having classical sign and symptoms of Dushta Pratishyaya (Chronic Sinusitis) were registered and were randomly divided into two groups (Group A- Vyaghri Haritaki Avaleha and Anutaila Nasya, Group B- Vyaghri Haritaki Avaleha). The patients were given Vyaghri Haritaki Avaleha for the duration of two months and Anutaila Nasya in 3 sittings of seven days in each with the interval of seven days. Total 26 patients completed the treatment, 13 in each. Obtained data was statistically analyzed with the help of student ' $t$ ' test. The study reveals that in both the groups no patient was totally cured. $46.15 \%$ and $53.85 \%$ patients got marked relief, $38.46 \%$ and $23.08 \%$ patients got moderate relief, $15.38 \%$ and $23.08 \%$ patients got mild relief in signs and symptoms of the disease in Group A and B respectively. None of the patients remained unchanged.
\end{abstract}

Key words: Anutaila, Chronic Sinusitis, Dushta Pratishyaya, Nasya, Vyaghri Haritaki Avaleha

\section{Inroduction}

Pratishyaya has been a major problem to the physicians since long back, this is because one separate chapter has been devoted to it after explaining Nasagataroga in Shusruta Samhita.(1) Unlike other nasal diseases, we get detailed description of Pratishyaya, with specific etiopathogenesis, classification, symptomatology, complications and management.

Pratishyaya by word itself indicates that it is recurrent in nature. Vata is the main Dosha and Kapha Pitta and Rakta are associated Dosha. (2) If these Dosha are vitiated more due to patient's improper dietary and behavioral habits and if Pratishyaya is not managed properly, lead to a severe and complicated condition called Dushta Pratishyaya-which is very difficult to treat and causes lot of complications like Badhirya (Deafness), Andhata (Blindness), Ghrananasa (Anosmia) etc.(3)

The features of the disease Dushta Pratishyaya

*Corresponding Author:

Parth P Dave

PhD Scholar,

Department of Shalakya Tantra,

IPGT\&RA, Gujarat Ayurved University,

Jamnagar -361008.

Mobile No. +91 - 9638948973

E-mail: drppdave88@gmail.com in general are similar to that of chronic sinusitis (rhinosinustis) in modern science.

Nose is a sense organ which performs two functions i.e. olfactory and respiratory. Due to its direct contact with external environment it is exposed to lot of microorganisms \& pollutants present in the atmosphere. Due to the increased environmental pollution, faulty lifestyle and decreased immunity; rhinitis (acute nonspecific rhinitis- common cold) is one of the most common acute infections affecting the body.(4) If this stage is not properly treated; it will cause the spread of infection into sinuses and results into sinusitis and later on chronic sinusitis (rhinosinusitis).(5) Chronic sinusitis is a long-term inflammation of the sinuses. It is diagnosed when symptoms of sinusitis persist for longer than 12 weeks despite treatment. Because of this, the mucous membranes in the nose and paranasal sinuses are constantly inflammed and become thickened.

Medical therapy is directed toward controlling predisposing factors, treating concomitant infections, reducing edema of sinus tissues, and facilitating the drainage of sinus secretions. The goal in surgical treatment is to re-establish sinus ventilation and to correct mucosal opposition in order to restore the mucociliary clearance system. Surgery strives to restore the functional integrity of the inflamed mucosal lining.

Many treatment modalities are propounded by ancient scholars for this disease according to condition of patient and progression of disease.(6) Though all 
Acharya had described Dushta Pratishyaya as a complicated condition and with poor prognosis,(7) still a better management can be provided to the patient with internal and local medication without any side effects.

The places with high levels of atmospheric pollution, damp temperature climates with high concentration of pollens are associated with a higher prevalence of this disease. Jamnagar being known for Industrial pollution and having more dusty and humid environment, respiratory infections report a large number of cases. Approximately $50-60 \%$ of the ENT patients attending Shalakya O.P.D., have complaint of this Rhinitis and associated sinusitis.

Considering all these facts, a clinical trial on Dushta Pratishyaya was carried out to find out a treatment protocol for management of the same. For this study, Nasya with Anutaila and Vyaghri Haritaki Avaleha orally were selected. As Dushta Pratishyaya (Chronic Sinusitis) is a chronic condition of Dosha accumulation in particular Nasa and Shira; which happens mainly due to Sanga type of Srotodushti; administration of Sneha Virechana Nasya of Anu Taila (8) was selected for Dosha Sravana and Srotoshudhdhi. On the other hand, due to decreased immunity, recurrences are very common. According to Ayurveda, Rasayana can be used for improvement of immunity. So many Rasayana preparations are described in various texts, out of which Vyaghri Haritaki Avaleha (9) was selected for internal medication, as it is indicated for Peenasa (Chronic rhinitis/sinusitis) and also having Rasayana and anti-inflammatory effect.

\section{Aims and objectives}

To study the disease Dushta Pratishyaya (Chronic Sinusitis) in Ayurvedic and modern parlance.

To assess the role of Anutail Nasya and Vyaghri Haritaki Avaleha in Dushta Pratishyaya (Chronic Sinusitis).

\section{Materials and methods Patient selection:}

Patients attending the O.P.D. and I.P.D of Department of Shalakya (E.N.T. unit), were selected for the study, irrespective of their sex, religion, occupation, education etc. Total 30 patients were registered for the study. An elaborative case-taking proforma was specially designed for the purpose of incorporating all aspects of the disease on Ayurvedic and modern parlance.

Informed consent was taken from all the registered patients for the trial.

\section{Sampling technique:}

A total no. of 30 patients were divided into two groups by simple random sampling method.

Study was started after getting ethical clearance from institutional ethics committee.

\section{Inclusion criteria}

Patients fulfilling the diagnostic criteria which are based on symptomatology of Dushta Pratishyaya explained in Ayurvedic classics and chronic sinusitis were selected.

- Subjective Criteria- Patients having symptoms of nasal discharge, nasal blockage, local pain, headache, nasal stuffiness, anosmia etc.

- Objective criteria- Anterior rhinoscopic examination, Radiological examination of paranasal sinuses, nasal endoscopy, C-reactive protein test (CRP Test), hematological examination.

\section{Exclusion criteria}

- Patients aged below 12 years and above 70 years.

- Chronic debilitating infectious diseases.

- Cases which require surgical treatment.

\section{Investigations}

Following investigations were carried out before and after treatment.

- Hematological examination: $\mathrm{Hb} \%, \mathrm{TC}, \mathrm{DC}, \mathrm{ESR}$.

- Urine examination: Routine and microscopic

- Radiological examination of para nasal sinuses (Xray PNS (Waters view \& Caldwell's view)).

- Diagnostic nasal endoscopy.

\section{Grouping of patients}

- Group A - In this group patients were administered Vyaghri Haritaki Avaleha orally and Marsha Nasya with A nutaila.

- Group B - In this group patients were administered Vyaghri Haritaki Avaleha orally.

\section{Drug and posology \\ Preparatory phase:}

Before starting the treatment, Deepana-Pachana with Trikatu Churna (3-5 gm. BD) and Koshtha Shudhdhi with Eranda Bhrishta Haritaki (5 gm at Bed time) was given for three days to all the patients. Before Nasya, Urdhava Jatrugata Abhyanga and Swedana was done as Purvakarma.

\section{Treatment phase:}

\section{Vyaghri Haritaki Avaleha}

Form: Avaleha.

Route of Administration: Oral.

Dose: 5 - 10gm/Two times a day after food with luke warm water.

Duration: 2 months.

\section{Anutaila}

Form of Nasya Drug: Taila (Sneha).

Route of Administration: Nose.

Dose for Nasya: 8 drops in each nostril followed by Dhumpana.

Duration: Nasya was given once daily for continue seven days. This was repeated thrice with interval of seven days in between.

\section{Assessment of total effect of therapy:}

- Complete relief: $100 \%$ relief in subjective and objective signs and symptoms

- Marked relief: Above 75\% relief in subjective 
and objective signs and symptoms

- Moderate relief: $51-75 \%$ relief in subjective and objective signs and symptoms

- Mild relief: $26-50 \%$ relief in subjective and objective signs and symptoms

- No relief: Below 25\% relief in subjective and objective signs and symptoms

Statistical Analysis:

The effect of therapy in both the groups was assessed by applying student $\mathrm{t}$ test. The results obtained are considered highly significant for $\mathrm{p}<0.001$, significant for $\mathrm{p}<0.01, \mathrm{p}<0.05$, and insignificant for $\mathrm{p}>0.05$.

\section{Observations and Results:}

For this study total 30 patients were registered and randomly divided into two groups, among which 26 patients (13 patients in each group) completed the treatment.

Age:

Maximum number of the patients (40\%) belonged to the age group of 20-29 years. While $30 \%$ and $23.33 \%$ patients were from the age group of $40-49$ years and 30-39 years respectively.

Sex:

Majority of the patients were female i.e. $56.67 \%$ and rest patients were male i.e. $43.33 \%$.

\section{Surroundings:}

Maximum number of the patients i.e. $63.33 \%$ were from dusty surrounding followed by $30 \%$ were from smoky and $23.33 \%$ were from polluted surroundings.

\section{Chronicity:}

Maximum i.e. $46.67 \%$ patients were having chronicity of $1-5$ years. $33.33 \%$ patients were having the disease since 1 year. $20 \%$ were having chronicity of 5 10 years.

\section{Nasal examination:}

In nasal examination i.e. anterior rhinoscopy 93.33\% patients were having Deviated Nasal Septum (DNS). $66.67 \%$ patients had congestion. This is because of the body response to remove the retained discharge and also indicate a long standing inflammatory process. $60 \%$ patients were having turbinate hypertrophy.

\section{Nasal discharge:}

$46.67 \%$ patients had thick nasal discharge; followed by $30 \%$ had yellow discharge. $23.33 \%$ patients had watery discharge.13.33\% patients had purulent discharge.

\section{Sinus examination:}

$100 \%$ patients had right and left maxillary sinus tenderness on examination, $76.67 \%$ patients had right and left frontal sinus tenderness. On radiological examination $83.33 \%$ patients had frontal sinusitis. 60
$\%$ and $50 \%$ patients had right and left maxillary sinusitis respectively.

Table 1: Sinus examination wise distribution of 30 patients

A: Palpation:

\begin{tabular}{|c|c|c|c|c|c|}
\hline \multirow{2}{*}{\multicolumn{2}{|c|}{ Sinuses }} & \multicolumn{2}{|c|}{ No. of patients } & \multirow{3}{*}{$\begin{array}{l}\text { Total } \\
30\end{array}$} & \multirow{3}{*}{$\begin{array}{c}\% \\
76.67\end{array}$} \\
\hline & & \multirow{2}{*}{$\begin{array}{c}\begin{array}{c}\text { Group } \\
\text { A }\end{array} \\
15\end{array}$} & \multirow{2}{*}{$\begin{array}{c}\begin{array}{c}\text { Group } \\
\text { B }\end{array} \\
15\end{array}$} & & \\
\hline \multirow{2}{*}{ Frontal } & $\mathrm{Rt}$ & & & & \\
\hline & $\mathrm{Lt}$ & 15 & 15 & 30 & 76.67 \\
\hline \multirow{2}{*}{ Maxillary } & Rt & 12 & 11 & 23 & 100 \\
\hline & $\mathrm{Lt}$ & 12 & 11 & 23 & 100 \\
\hline \multirow{2}{*}{ Ethmoid } & $\mathrm{Rt}$ & 9 & 7 & 16 & 53.33 \\
\hline & $\mathrm{Lt}$ & 8 & 7 & 15 & 50 \\
\hline
\end{tabular}

B: Radiological:

\begin{tabular}{|c|c|c|c|c|c|}
\hline & & No. of & atients & & \\
\hline & & Groun & Group & Total & $\%$ \\
\hline & $\mathrm{Rt}$ & 13 & 12 & 25 & 83.33 \\
\hline & $\mathrm{Lt}$ & 14 & 11 & 25 & 83.33 \\
\hline & $\mathrm{Rt}$ & 12 & 6 & 18 & 60 \\
\hline & $\mathrm{Lt}$ & 9 & 6 & 15 & 50 \\
\hline
\end{tabular}

\section{Nidana:}

Maximum patients i.e. $60.33 \%$ had Ajirna. $50 \%$ patients had habit of Ati Ambu Pana and $43.33 \%$ patients were doing Sheeta Ambu Pana. $56.67 \%$ patients had exposure to Raja (dust).46.67\% patients were used to sleep in day times. $70 \%$ patients had short tempered nature.

\section{Chief and associated complaints:}

Maximum i.e. $96.67 \%$ patients had Shirashoola (headache) as their chief complaint. $86.67 \%$ patients had Shirogaurava (heaviness in head). Shirashoola and Shirogaurava were observed as a characteristic feature of the disease. Majority of the patients i.e. $90 \%$ and $73.33 \%$ patients had complaints of Nasavarodha (nasal obstruction) and Nasasrava (nasal discharge). $80 \%$ patients had post nasal drip. Post nasal drip will result a lot of descending infections like pharyngitis, laryngitis, coughing etc. 
Table 2: Chief and associated complaint wise distribution of 30 patients

\begin{tabular}{|c|c|c|c|c|}
\hline \multirow[b]{2}{*}{ Complaints } & \multicolumn{2}{|c|}{ No. of patients } & \multirow[b]{2}{*}{ Total } & \multirow[b]{2}{*}{$\%$} \\
\hline & $\begin{array}{l}\text { Group } \\
\text { A }\end{array}$ & $\begin{array}{l}\text { Group } \\
\text { B }\end{array}$ & & \\
\hline $\begin{array}{l}\text { Nasasrava } \\
\text { (Nasal } \\
\text { discharge) }\end{array}$ & 12 & 10 & 22 & 73.33 \\
\hline $\begin{array}{l}\text { Nasa Avrodha } \\
\text { (Nasal } \\
\text { blockage) }\end{array}$ & 12 & 15 & 27 & 90 \\
\hline $\begin{array}{l}\text { Gandha } \\
\text { Agyanata } \\
\text { (Anosmia) }\end{array}$ & 5 & 6 & 11 & 36.67 \\
\hline $\begin{array}{l}\text { Mukha } \\
\text { Daurgandhya } \\
\text { (Halitosis) }\end{array}$ & 2 & 4 & 6 & 20 \\
\hline $\begin{array}{l}\text { Shirah Shoola } \\
\text { (Headache) }\end{array}$ & 15 & 14 & 29 & 96.67 \\
\hline $\begin{array}{l}\text { Kasa } \\
\text { (Coughing) }\end{array}$ & 2 & 8 & 10 & 33.33 \\
\hline $\begin{array}{l}\text { Jwara } \\
\text { (Fever) }\end{array}$ & 9 & 13 & 22 & 73.33 \\
\hline
\end{tabular}

Effect of therapies on subjective symptoms (13 patients in each group)

Nasasrava was reduced in $80.77 \%$ patients in Group A $(\mathrm{p}<0.001)$, while $88.22 \%$ patients in Group B $(\mathrm{p}<0.01)$.

Nasaavarodha was reduced in $66.46 \%$ patients in Group A, while $84.21 \%$ patients in Group B. Both these values are statistically highly significant $(\mathrm{p}<0.001)$.

Shirashoola was reduced in $72.73 \%$ patients in Group A, while $75.86 \%$ patients in Group B. Both these values are statistically highly significant $(\mathrm{p}<0.001)$.

In Gandhagyanata $50 \%$ relief was observed in Group A which is statistically significant $(\mathrm{p}<0.05)$ and $42.86 \%$ relief was found in Group B which is statistically not significant ( $\mathrm{p}>0.05)$.

Mukhadaurgandhya was reduced in $100 \%$ of the patients in group $\mathrm{A}$ and $71.43 \%$ in Group B. Because of the less number this data couldn't be analyzed statistically.

In associated symptoms like Kasa and Jwara 100 $\%$ relief was observed in both the groups.

Table 3: Effect of therapies on chief and associated complaints in both the groups:

\begin{tabular}{|l|l|l|l|l|}
\hline \multirow{2}{*}{ Complaint } & \multicolumn{2}{|c|}{ Group A } & \multicolumn{2}{c|}{ Group B } \\
\cline { 2 - 5 } & $\begin{array}{l}\text { \% } \\
\text { relief }\end{array}$ & $\mathbf{P}$ & $\begin{array}{l}\text { \% } \\
\text { relief }\end{array}$ & P \\
\hline Nasasrava & 80.77 & $<0.001$ & 88.24 & $<0.01$ \\
\hline Nasaavrodha & 66.46 & $<0.001$ & 84.21 & $<0.001$ \\
\hline $\begin{array}{l}\text { Gandha- } \\
\text { Agyanta }\end{array}$ & 50 & $<0.05$ & 42.86 & $>0.05$ \\
\hline Shirashoola & 72.73 & $<0.001$ & 75.86 & $<0.001$ \\
\hline $\begin{array}{l}\text { Mukha } \\
\text { daurgandhya }\end{array}$ & 100 & - & 71.43 & - \\
\hline Kasa & 100 & - & 100 & - \\
\hline Jwara & 100 & - & 100 & - \\
\hline
\end{tabular}

\section{Effect of therapy on examination of sinuses:}

\section{Rt. maxillary sinus:}

In $80 \%$ patients in Group A and $75 \%$ patients in Group B, relief was observed on tenderness of sinuses. Both these values are statistically highly significant $(\mathrm{p}<0.001)$. In $38.46 \%$ patients in Group A and $25 \%$ patients in Group B, haziness or opacity was reduced on radiological examination. Among these, the result of Group A is statistically significant $(p<0.05)$ but in case of Group B it is statistically not significant ( $p>0.05)$.

\section{Lt. maxillary sinuses:}

In $85 \%$ patients in Group A and $83.33 \%$ patients in Group B, relief was observed on tenderness of sinuses. Both these values are statistically highly significant $(\mathrm{p}<0.001)$. In $60 \%$ patients in Group A and $33.33 \%$ patients in Group B haziness or opacity was reduced on radiological examination. Among these, the result of Group A is statistically significant $(p<0.01)$ but

Table 4: Effect of therapies on sinus examinations:

\begin{tabular}{|c|c|c|c|c|c|c|c|c|}
\hline \multirow{3}{*}{ Sinuses } & \multicolumn{4}{|c|}{ Palpation } & \multicolumn{4}{|c|}{ Radiological } \\
\hline & \multicolumn{2}{|l|}{ Group A } & \multicolumn{2}{|l|}{ Group B } & \multicolumn{2}{|l|}{ Group A } & \multicolumn{2}{|l|}{ Group B } \\
\hline & $\%$ relief & $\mathbf{P}$ & $\%$ relief & $\mathbf{p}$ & $\%$ relief & $\mathbf{P}$ & $\%$ relief & $\mathbf{P}$ \\
\hline Rt.Maxillary & 80 & $<0.001$ & 75 & $<0.001$ & 38.46 & $<0.05$ & 25 & $>0.05$ \\
\hline Lt.Maxillary & 85 & $<0.001$ & 83.33 & $<0.001$ & 60 & $<0.01$ & 33.33 & $>0.05$ \\
\hline Rt.Frontal & 76.19 & $<0.001$ & 81.25 & $<0.001$ & 50 & $<0.05$ & 25 & $>0.05$ \\
\hline Lt.Frontal & 76.19 & $<0.001$ & 81.25 & $<0.001$ & 61.54 & $<0.05$ & 10 & $>0.05$ \\
\hline
\end{tabular}


in case of Group B it is statistically not significant $(\mathrm{p}>0.05)$.

\section{Rt. frontal sinuses:}

In $76.19 \%$ patients in Group A and $81.25 \%$ patients in Group B, relief was observed on tenderness of sinuses. Both these values are statistically highly significant $(\mathrm{p}<0.001)$. But Group B showed better result. In $50 \%$ patients in Group A and $25 \%$ patients in Group B haziness or opacity was reduced on radiological examination. Among these, the result of Group A is statistically significant $(p<0.05)$ but in case of Group B it is statistically not significant $(\mathrm{p}>0.05)$.

\section{Lt. frontal sinuses:}

In $76.19 \%$ patients in Group A and $81.25 \%$ patients in Group B, relief was observed on tenderness of sinuses. Both these values are statistically highly significant $(\mathrm{p}<0.001)$. But Group B showed better result. In $61.54 \%$ patients in Group $A$ and $10 \%$ patients in Group B haziness or opacity was reduced on radiological examination. Among these, the result of Group A is statistically significant $(p<0.05)$ but in case of Group B it is statistically not significant ( $>00.05)$.

\section{Overall effect of therapies on subjective and objective parameters:}

In both the groups no one was totally cured. In Group A $46.15 \%$ patients and in Group B $53.85 \%$ patients got marked relief in signs and symptoms of the disease. In Group A $38.46 \%$ patients and in Group B $23.08 \%$ patients got moderate relief in signs and symptoms of the disease. In Group A $15.38 \%$ patients and in Group B 23.08 \% patients got mild relief in signs and symptoms of the disease. None of the patients remained unchanged.

Table 5: Overall effect of therapy

\begin{tabular}{|c|c|c|c|c|c|}
\hline \multirow{2}{*}{$\begin{array}{l}\text { Overall } \\
\text { effect }\end{array}$} & \multicolumn{2}{|c|}{ Group A } & \multicolumn{2}{|c|}{ Group B } & \multirow{2}{*}{$\begin{array}{l}\text { Total } \\
\%\end{array}$} \\
\hline & $\begin{array}{l}\text { No. } \\
\text { of } \\
\text { pt. }\end{array}$ & $\%$ & $\begin{array}{l}\text { No. } \\
\text { of } \\
\text { pt. }\end{array}$ & $\%$ & \\
\hline $\begin{array}{l}\text { Complete } \\
\text { relief }\end{array}$ & 0 & 0 & 0 & 0 & 0 \\
\hline $\begin{array}{l}\text { Marked } \\
\text { relief }\end{array}$ & 6 & 46.15 & 7 & 53.85 & 50 \\
\hline $\begin{array}{l}\text { Moderate } \\
\text { relief }\end{array}$ & 5 & 38.46 & 3 & 23.08 & 30.77 \\
\hline Mild relief & 2 & 15.38 & 3 & 23.08 & 19.23 \\
\hline No relief & 0 & 0 & 0 & 0 & 0 \\
\hline
\end{tabular}

\section{Discussion:}

\section{Age and sex:}

According to references chronic sinusitis can affect any age group, but young and middle age group persons are affected the most. In this study also the same observations were found. Both the sex are equally affected from the disease but in present study female were affected more than male.

\section{Surroundings of residence and work place:}

Most patients were from dusty, smoky or polluted environment; Rajah Sevana is one of the Sadyojanaka cause of Prtishyaya.

\section{Chronicity:}

Maximum patients were having chronicity of 1-5 years, and $20 \%$ were having chronicity of 5-10 years. This factor directly influences the prognosis.

\section{Nasal examination:}

More than $90 \%$ of patients were having DNS, DNS is a factor which plays a key role in blocking of the frontonasal duct (Frontal sinus ostium) and the ostia draining the ethmoid and maxillary sinuses which lead the sinusitis to a chronic phase. Majority of the patients were having turbinate hypertrophy that plays a major role in the blockage of sinus ostia which hampers the natural drainage system, resulting in sinusitis.

\section{Nasal discharge:}

Majority of the patients were having thickyellowish or purulent nasal discharge, except $23.33 \%$ patients having watery nasal discharge. This data supports the fact that in Dushta Pratishyaya there will be Puyopam- Grathita Srava.(10)

\section{Sinus examination:}

All the observations point out that anterior group of sinuses are affected more than posterior group. Fronto-maxillary sinusitis was the most common variety found in this study. Amongst 30 patients $53.33 \%$ and 50 $\%$ patients had right and left ethmoid sinus tenderness respectively. But with X-ray Water's view of paranasal sinuses to rule out ethmoid sinusitis was not possible.

\section{Nidana:}

Majority of the patients were having Ajeerna, most of patients were having habit of Ati Jalapana and Shitambu Sevana. Aharaja Nidana are reflection of the changing and busy lifestyle which played a role in the pathogenesis of the disease. Most of patients were having, Viharaja Nidana like Ritu Vaishamya, Raja, Dhuma Sevana etc. they are unavoidable etiological factors which are described by Acharya Sushruta as Sadyojanaka Nidana for Pratishayaya. Chronic contact with such unavoidable Nidana will nullify the effect of the therapy. It can be one reason why the patients were not getting relief even after taking treatment for years. Krodha as Manasika Nidana is also reflection of the Prakriti of the patients and also today's lifestyle. This also plays a major roon le in the etiopathogenesis of the disease.

\section{Chief and associated complains:}

The inflammation of nasal and sinus mucosa causes hyperemia, exudation of fluid and increased activity of serous and mucous glands. This causes nasal discharge. Increased blood flow due to infection causes 
oedema of nasal and sinus mucosa which results in nasal obstruction. Deviated Nasal septum and hypertrophied turbinates worsen the conditions like Nasasrava and Nasavarodha.

Effect of therapy on chief and associated complains: In both the group statistically significant relief was observed in Nasasrava, Nasaavarodha and Shirashoola like symptoms. Oral drug administration of Vyaghri Haritaki Avaleha helped in reduction of inflammation and infection, and thus relieved Nasaavarodha due to oedema and Nasasrava due to infection and over activity of mucous secreting glands. When both inflammation and infection are checked; the sinuses get proper drainage and ventilation. As a consequence Shirshoola was reduced. In symptom of Gandhagyanta significant result was not found in group B. Smell perception is done by olfactory receptors situated at olfactory bulb. If the smell perception is obstructed due to oedema of mucosal linning, it can be restored by reducing inflammation. But if the olfactory epithelium is destroyed once cannot be restored. In group A Nasya was given which acts locally and helped in reduction of oedema. Thus in the symptom of Gandha Agyanta Group A showed better result.

Associated symptoms like Kasa, Jwara and Mukhadaurgandhya were cured with the treatment of main disease.

\section{Effect of therapy on sinus examination:}

On the above data, we can see that subjectively both the groups showed statistically significant improvement but objectively Group A showed statistically significant result while Group B didn't show statistically significant improvement. This happened because of Nasya Karma, as drainage of retained secretions is facilitated by local Swedana and Aushdha instillation. This helps in early and better improvement in local pathology.

\section{Overall effect of therapy:}

Maximum numbers of patients got marked relief. In both the groups none of the patient was totally cured, this is because the etiological factors of the disease are such as dust, moisture, wind, smoke, pollution, pollens etc. These are unavoidable environmental factors which cannot be completely avoided. So if the exposure to Nidana is continuous simultaneously with Chikitsa one cannot get proper or desired result. The result also depends upon the chronicity. In Ayurveda it is said that if the disease is chronic (Purana) it is difficult to treatYapya(8). Moreover the patients' lowered immunity status is also one of the causes. It may require long time to boost up the immunity to fight against recurrences.

The variation of results also depends upon Roga Bala, Rogi Bala and the Bhishagvashyata-compliance/ obedience of the patient.

\section{Probable mode of action of Vyaghri Haritaki Avaleha}

Two main ingredients of Vyaghri Haritaki Avaleha are Haritaki and Kantkari. Haritaki has
Tridoshshamaka property and Kantkari has KaphaVatahara property. Both the drugs have KaphaVatahara properties. Kantkari is an immunostimulating agent.(11) Haritaki also has immunomodulatory activity.(12) Haritaki is having Shothahara and Rasayana property also. Medicines of the Rasayana group are believed to promote health, immunity, and longevity. Prakshepa Dravyas-Trikatu and Chaturjata have Ushna- Tikshna properties, which promote Agni, indirectly help in absorption and metabolism of active principles. Trikatu helps to increase the bioavailability of the medicine and more over removes the Srotorodha at the cellular level. Trikatu is the best bioavailability enhancers, which helps in maintaining the major therapeutic principles in the systemic circulation for longer duration and they are good Anulomana, Deepana and Pachana Dravyas and subsides the aggravated Vata. Trikatu possesses potential immunomodulatory activity and has therapeutic potential for the prevention of autoimmune diseases. (13) Madhu has Kaphahara and Chhedana properties. Guda is also used in this formulation and Haritaki with guda is said to be Tridoshahara.

Anti-inflammatory activity of Terminalia chebula Retz. was at least in part due to its modulatory effect on pro-inflammatory cytokine expression in the inflammation.(14) Antibacterial Activity of Hydroalcoholic Extract of Terminalia chebula Retz. on different Gram-positive and Gram-negative Bacteria is also well documented. (15) This resolves infection and inflammation and removes obstruction at sinus ostia \& also liquifies stagnant discharge in sinuses, thus facilitates drainage.

Thus the formulation Vyaghri Haritaki Avaleha acts by rectifying Vayu by Ushna Veerya, Madhura Rasa, Anulomana property and Sroto-Shodhana by its Katu- Tikta-Kashaya Rasa, Ushna Veerya and Katu Vipaka, thus breaking the Samprapti. It will open the obstructed path like sinus ostia and facilitate the drainage of collected discharge. The formulation is having qualities like Madhura Rasa, which increases the Bala (strength) which is usually decreased in chronic condition, thus improving the condition of the patient.

\section{Probable mode of action of Anutaila Nasya}

Instead of detailed description of the mode of action of Nasya Karma, Acharya Charaka and Vagbhatta have given some details regarding it. They mentioned that the medicine administrated through Nasya can easily spread into Shira and get absorbed and eliminates the Dosha from Urdhva Jatrugata Pradesha. Urdhvajatrugata Abhyanga and Swedana are done before Nasya. These pre procedural measures help in facilitating drug absorption. The drug administration is done in head low position, which plays a major role in retaining the instilled medicine in the nasopharynx, thus increasing the contact time with mucosa. After the absorption of the drug it may follow neural (olfactory and trigeminal) and circulatory (cavernous sinus) course to reach the site of action. It can influence the psychic level (limbic system), sensory level, motor level 
(Trigeminal nerve) and general circulation and ultimately produce the action. (Excitation or sedation).

Due to Sukshama-Vyavayi Guna and special preparatory process, Anutaila possess a good spreading capacity through minute channels. Tikta-Katu Rasa, Laghu- Tikshna Guna, Ushna Veerya and Katu-Vipaka make Srotoshodakatwa. By the above two properties the Nasya drug removes the obstruction of natural sinus ostia and facilitate the drainage of purulent discharge. Indriyadardhyakaratwa, Balya, Preenana and Brimhana properties can increase general and local immunity. Madhura Rasa, Sheeta Veerya, Snigdha Guna and Tridoshahara properties will promote the nourishment of Dhatu which ultimately increases the general and local immunity (mucosal health). This immunomodulation will reduce the frequent episodes of inflammation in nasal cavity and sinuses. Majority of ingredients possess anti-inflammatory activity which also prevent the inflammatory process. The local irritation made by the drug is helpful to liquefy the purulent sputum and ultimately expulsion. The bacteriostatic property of ingredients will arrest the secondary infection.

\section{Conclusion:}

Recurrent attack of Pratishyaya continue for months and years, will turn in to a chronic phase with much complication called Dushta Pratishyaya. On the basis of similarity between the signs, symptoms, complications, prognosis and chronicity, chronic sinusitis can be correlated with Dushta Pratishyaya.

Both the group showed almost equal results in different symptoms. But objectively Group-A (Vyaghri Haritaki Avaleha with Anutaila Nasya) showed better result. So it can be said say that Nasya with oral medication may be much beneficial for early cure of the disease.

\section{References:}

1) Sushruta. Sushruta Samhita with nibandhasangraha commentary of Dalhana and nyayachandrika Panjika on Nidanasthana commentary of Gayadasacharya, Ed. By Vd. Jadavaji Trikamji Acharya \& Narayana Ram Acharya. Varanasi; Chaukhamba Surbharati Prakashana; 2010. 651p.

2) Sushruta. Sushruta Samhita with nibandhasangraha commentary of Dalhana and nyayachandrika Panjika on Nidanasthana commentary of Gayadasacharya, Ed. By Vd. Jadavaji Trikamji Acharya \& Narayana Ram Acharya. Varanasi; Chaukhamba Surbharati Prakashana; 2010. 651p.

3) Sushruta. Sushruta Samhita with nibandhasangraha commentary of Dalhana and nyayachandrika Panjika on Nidanasthana commentary of Gayadasacharya, Ed. By Vd. Jadavaji Trikamji Acharya \& Narayana Ram Acharya. Varanasi; Chaukhamba Surbharati Prakashana; 2010. 652p.
4) Bhargava K. B.. A Short Text Book of ENT Diseases. 9ed. Mumbai; Usha Publications; 2011. $155 \mathrm{p}$.

5) Kumar Shyamal. Fundamentals of Ear Nose and Throat \& Head and Neck Diseases. 6ed. Culcutta; Mohendra Nath Paul; 1996. 260,266p.

6) Sushruta. Sushruta Samhita with nibandhasangraha commentary of Dalhana and nyayachandrika Panjika on Nidanasthana commentary of Gayadasacharya, Ed. By Vd. Jadavaji Trikamji Acharya \& Narayana Ram Acharya. Varanasi; Chaukhamba Surbharati Prakashana; 2010. 652p.

7) Sushruta. Sushruta Samhita with nibandhasangraha commentary of Dalhana and nyayachandrika Panjika on Nidanasthana commentary of Gayadasacharya, Ed. By Vd. Jadavaji Trikamji Acharya \& Narayana Ram Acharya. Varanasi; Chaukhamba Surbharati Prakashana; 2010. 652p.

8) Vagbhata. Ashtanga Hridaya with sarvanga Sundari Arunadatta commentary of Arundatta and ayurvedarasayana commentary of Hemadri, Ed. By Pt. Sadashiva Shastri Paradakara. Varanasi; Chaukhamba Surbharati Prakashana; 2007. 293p.

9) Kaviraj Govind Das Sen. Bhaishjya Ratnavali with sidhdhiprada commentary. Varanasi; Chaukhamba Surbharati Prakashana; 2005. 297p.

10) Vagbhata. Ashtanga Hridaya with sarvanga Sundari Arunadatta commentary of Arundatta and ayurvedarasayana commentary of Hemadri, Ed. By Pt. Sadashiva Shastri Paradakara. Varanasi; Chaukhamba Surbharati Prakashana; 2007. 853p.

11) Sultana R, Khanam S, Devi K. Evaluation of Immunomodulatory activity of Solanum xanthocarpum fruits aqueous extract. Der Pharmacia Lettre 2011; 3(1); 247-253.

12) Vaibhav Aher, ArunKumar Wahi. Immunomodulatory Activity of Alcohol Extract of Terminalia chebula Retz Combretaceae. Tropical Journal of Pharmaceutical Research 2011; 10 (5); $567-575$.

13) Jain Neha, Mishra RN. Immunomodulator activity of Trikatu. International Journal of Research in Pharmaceutical and Biomedical Sciences 2011; 2(1) 160-164.

14) Vinod Nair, Surender Singh and Yogendra Kumar Gupta. Anti-arthritic and disease modifying activity of Terminalia chebula Retz. in experimental modelsThe Journal of Pharmacy and Pharmacology. 2010; 62(12); 1801-186.

15) Ashish Agrawal et al. Antibacterial Activity of Hydroalcoholic Extract of Terminalia chebula Retz. on Different Gram-positive and Gram-negative Bacteria. International Journal of Pharmaceutical \& Biological Archives. 2010; 1(4); 485-488. 